\title{
Sea urchins, macroalgae and coral reef decline: a functional evaluation of an intact reef system, Ningaloo, Western Australia
}

\author{
C. L. Johansson ${ }^{1,2, *}$, D. R. Bellwood ${ }^{1}$, M. Depczynski ${ }^{3}$ \\ ${ }^{1}$ Australian Research Council Centre of Excellence for Coral Reef Studies and School of Marine and Tropical Biology, \\ James Cook University, Townsville, Queensland 4811, Australia \\ ${ }^{2}$ AIMS@JCU, Australian Institute of Marine Science, School of Marine and Tropical Biology, James Cook University, \\ Townsville, Queensland 4811, Australia \\ ${ }^{3}$ Australian Institute of Marine Science, UWA Oceans Institute, Crawley, Western Australia 6009, Australia
}

\begin{abstract}
The number of relatively untouched coral reefs worldwide is rapidly decreasing. Nevertheless, one coral reef ecosystem remains relatively intact: the largest west-continental reef ecosystem in the world, Ningaloo Reef in Western Australia. This study investigated the status of 2 potential bio-indicators for coral reef decline, macroalgae and sea urchin densities, on this reef. Surprisingly, both were abundant, with the presence of extensive macroalgal beds in the sandy lagoon and a sea urchin-dominated reef slope. The algal distribution on Ningaloo reflected marked crossshelf variation in the composition of fish functional groups, with only the back reef and the reef slope exhibiting high grazing rates (completely scraped every 43 and 59 d, respectively). Estimated bioerosion rates by fishes ranged between 1 and $2.3 \mathrm{~kg} \mathrm{~m}^{-2} \mathrm{yr}^{-1}$. Echinoids only played a significant role in bioerosion on the reef slopes owing to their high abundance in that habitat ( $>12$ individuals $\mathrm{m}^{-2}$ ). Here, estimated echinoid erosion equalled that of the most abundant excavating parrotfish, Chlorurus sordidus. High echinoid and macroalgal abundances on this relatively intact reef system highlight the need for caution when using these metrics for evaluating reef ecosystem condition.
\end{abstract}

KEY WORDS: Ningaloo · Herbivory · Echinoderms · Algae · Parrotfish · Functional groups · Ecosystem function · Coral reef

\section{INTRODUCTION}

The world's coral reefs are in decline (Hughes et al. 2003, Pandolfi et al. 2003, Bellwood et al. 2004, Graham et al. 2007) and the pressure from human exploitation and climate change are having impacts on ecosystems that are difficult to predict (Lough 2008, Nyström et al. 2008, De'ath et al. 2009). Numerous reefs around the globe are exhibiting various levels of degradation. Although some are considered to be healthy and well managed, others show clear signs of change in critical functions and processes (Wilkinson 2008, Paddack et al. 2009). Nevertheless, the responses of reefs to various disturbance events tend to vary as a result of local and regional variation in ecosystem structure and processes (Hughes 1994, Ledlie et al. 2007, Lokrantz et al. 2008, Nyström et al. 2008). Despite the diversity of responses to coral reef degradation, 2 widely recognized indicators of coral reef decline have been identified: macroalgal cover and sea urchin density (Hughes 1994, McClanahan \& Mutere 1994, Jackson et al. 2001, McManus \& Polsenberg 2004). These 2 taxa tend to increase in abundance and biomass on degrading reefs and may create undesirable alternative states (Done 1992, McClanahan \& Mutere 1994, McManus \& Polsenberg 2004, Bellwood et al. 2006, Mumby et al. 2006, Norström et al. 2009). 
In both intact and human-disturbed ecosystems, macroalgal biomass appears to be primarily regulated by the abundance and biomass of herbivores, especially fishes (McCook 1996, 1999, Bellwood et al. 2006, Burkepile \& Hay 2008). Algal biomass may also increase in response to the influx of nutrient-enriched terrestrial run-off. This is usually linked to agricultural land-use practices and human coastal development (Schaffelke 1999, Done et al. 2007, De'ath \& Fabricius 2010). Similarly, increases in echinoid numbers have been identified as direct consequences of the overfishing of sea urchin predators (Hay 1984, McClanahan 1995), potentially increasing urchin densities and erosion by urchins to damaging levels. In both cases, overfishing of critical functional groups, i.e. key algal consumers and echinoid predators, weakens and reduces the links and processes within the system (Bellwood et al. 2004, Mumby et al. 2006, Hughes et al. 2007), and can potentially increase macroalgae and sea urchin populations to a state where high abundances are detrimental to the system and increase the possibility of ecosystem shifts (Norström et al. 2009).

It is widely accepted that there are 2 main drivers controlling macroalgae abundance on coral reefs: herbivores and nutrients. There is, however, considerable disagreement in the relative contribution of the two. Most evidence supports the dominant role of herbivory (McCook 1996, Burkepile \& Hay 2008). Nevertheless, there is an ongoing argument that macroalgae is primarily influenced by water quality and/or a combination of low herbivory and reduced water quality, especially in areas where terrestrial inputs are present (Schaffelke 1999, De'ath \& Fabricius 2010). To date, most macroalgal stands in coral reef ecosystems have been reported in areas with limited herbivore activity (Mumby et al. 2006, Wismer et al. 2009) and/or areas where macroalgal distributions have been linked to declining water quality (De'ath \& Fabricius 2010). However, it has also been suggested that macroalgal biomass is not necessarily influenced by human activity, but may be a natural characteristic of some coral reef ecosystems (Vroom et al. 2006, Bruno et al. 2009, Wismer et al. 2009, Vroom et al. 2010) and strongly related to coral cover (Williams et al. 2001).

Ongoing human pressure on coral reefs seems to be unavoidable and coral reef health is consequently measured against an increasing level of human-generated disturbance (Hughes et al. 2003, Pandolfi et al. 2003). In this context, the Great Barrier Reef (GBR) is considered to be one of the healthiest and best-managed reefs in the world (Pandolfi et al. 2003, Wilkinson 2008). However, the GBR has a long history of fishing (Jackson et al. 2001) and has experienced several outbreaks of crown-of-thorn starfish (Hart \& Klumpp 1996). Furthermore, not only does it receive high levels of freshwater input, which deliver sediment and nutrient enriched waters to the inshore reefs (Done et al. 2007, De'ath \& Fabricius 2010), but it is also exposed to increasing natural disturbances like cyclones (Fabricius et al. 2008) and coral bleaching, as a result of climate change (Hughes et al. 2007). The combined effects, however, are difficult to interpret. Considering the wide range of both natural and human induced impacts, the GBR may not be as healthy as once considered.

However, situated on the central west coast of Australia is a large coral reef system that appears to be less disturbed than the GBR, Ningaloo Reef (Roberts et al. 2002). Ningaloo is exceptional in that it supports the largest coral reef system on the west coast of any continent. Here, the usual west-continental, upwellingdriven, nutrient-rich, cool waters are suppressed by the warm, south-flowing Leeuwin Current (LC) enabling Ningaloo to support coral communities (Hanson et al. 2005, Woo et al. 2006, Furnas 2007). Ningaloo Reef, situated within Ningaloo Marine Park, has been subject to various levels of protection since the 1980s. In contrast to the GBR, Ningaloo has experienced limited commercial fishing activity. One of the few documented cases of a commercial fin-fishery is for reefassociated lethrinids from 1987 to 1992 (Moran et al. 1993). The fishery is regulated within the marine park and no commercial fin-fishing activities are currently allowed within the sanctuary zones. Additionally, Ningaloo is affected by minimal freshwater run-off and extremely low human coastal development (Cassata \& Collins 2008). Disturbances to this reef system are dominated by natural events, such as high wave energy and cyclones (Collins et al. 2003). Ningaloo Reef, therefore, experiences little direct human impacts compared to other coral reef systems, including the GBR. The unusual characteristics of Ningaloo present an opportunity to explore a relatively intact coral reef, and may provide insights to the benthic community structure and ecosystem processes in an extensive coastal reef system where direct human impacts are limited (Roberts et al. 2002).

The aim of the present study was to provide a preliminary quantitative evaluation of the structural and functional characteristics of Ningaloo Reef's benthic and herbivorous fish communities, including 2 potential indicators of coral reef decline: macroalgae and echinoids.

\section{MATERIALS AND METHODS}

Study sites. Surveys were conducted in the central and northern parts of Ningaloo Marine Park in April 2009. Ningaloo Reef is a narrow fringing reef system that stretches $\sim 280 \mathrm{~km}$ along the central Western 
Australian coast between latitudes $21^{\circ} 47^{\prime}$ and $24^{\circ} 00^{\prime} \mathrm{S}$ (Fig. 1). The shallow section of the slope, crest and flat are exposed to high wave energy, while the back reef and the lagoon are relatively protected. The slope falls gently from the crest to the continental shelf and has relatively low structural complexity near the reef edge (Collins et al. 2003). The back reef is relatively shallow, either patchy on sandy substrata or continuous, and receives a regular influx of oceanic waters coming over the crest and through passages into the lagoon. The lagoon stretches from the shore to the back reef and measures 0.5 to $6 \mathrm{~km}$ in width. It is predominantly sandy with patches of coral and/or macroalgal stands (Collins et al. 2003).

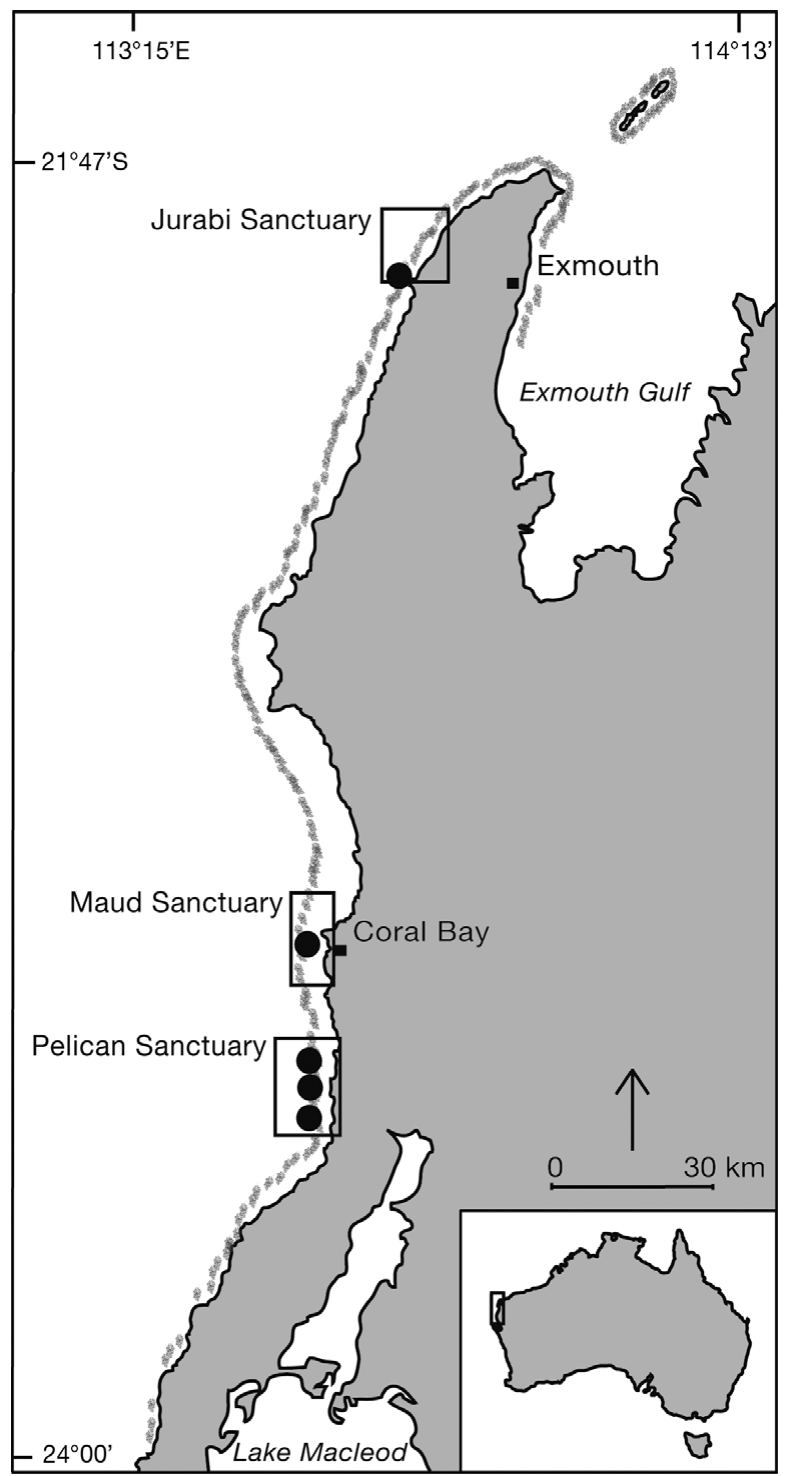

Fig. 1. Ningaloo Reef in Western Australia, showing the approximate locations of the 3 sanctuary zones, within which the 5 study sites are located
Five sites were selected along the northern and central part of Ningaloo Reef. Each site was located inside or on the border of 3 no-fishing sanctuary zones: Jurabi Sanctuary $\left(21^{\circ} 51^{\prime} \mathrm{S}, 113^{\circ} 59^{\prime} \mathrm{E}\right)$, Maud Sanctuary $\left(23^{\circ} 08^{\prime} \mathrm{S}, 113^{\circ} 45^{\prime} \mathrm{E}\right)$ and Pelican Sanctuary $\left(23^{\circ} 18^{\prime} \mathrm{S}\right.$, $113^{\circ} 46^{\prime} \mathrm{E}_{i} 23^{\circ} 19^{\prime} \mathrm{S}, 113^{\circ} 47^{\prime} \mathrm{E}$ and $23^{\circ} 20^{\prime} \mathrm{S}, 113^{\circ} 47^{\prime} \mathrm{E}$ ). For each site, 3 habitats were selected to quantify benthic cover and herbivore abundances. Wave activity reduced the accessibility to the reef crest and flat, and censuses were consequently restricted to the slope, back reef and lagoon. All dives were made during daylight hours between 09:00 and 16:00 h. All surveys on the slope were conducted between 6 and $10 \mathrm{~m}$, on the back reef between 2 and $8 \mathrm{~m}$, and in the lagoon between 3 and $5 \mathrm{~m}$.

Benthic surveys. At each of the 5 sites, benthic cover was surveyed in each habitat using fifteen $10 \mathrm{~m}$ transects. Transects were only deployed on hard benthic habitat, i.e. not on open sand. The benthic transects were separated by $10 \mathrm{~m}$ and deployed parallel to the coast. Each transect was treated as a replicate giving a total of 15 replicates per habitat per site. The benthic substratum at points immediately under each $1 \mathrm{~m}$ interval and at $1 \mathrm{~m}$ to each side were recorded giving a total of 33 points per transect (the 33 points were used to estimate proportional cover for each replicate transect). The substrata were classified to the lowest level possible and then grouped into the following substratum categories: live coral, dead coral, sand/rubble, epilithic algal matrix (EAM), pavement/matrix (P/M), macroalgae ( $\geq 15 \mathrm{~mm})$, crustose coralline algae (CCA) and other.

Herbivore censuses. Prior to the benthic surveys, five $5 \times 50 \mathrm{~m}$ transects were used to quantify fish abundance and biomass in each habitat at each of the 5 sites. The length of the transect was measured by a second diver who followed close behind the fish observer to avoid negative impacts on fishes as a result of diver presence (Fulton et al. 2001). Each transect was separated by at least $10 \mathrm{~m}$. Care was taken throughout the survey to account for the diver effect and not to count fish that were 'pushed along' transects or fish re-entering the field of observation. Prior to the survey the observer practised underwater size estimations using fish silhouettes. Four main roving herbivore groups were surveyed: Acanthuridae, Kyphosidae, Siganidae and parrotfishes (Labridae). The total length (TL) of each individual was recorded in $5 \mathrm{~cm}$ size classes and only included individuals $\geq 10 \mathrm{~cm}$ TL. Abundance estimates were later converted into biomass using published length-weight regressions supplemented by direct measurements (Table S1 in the supplement, see www.int-res.com/articles/suppl/ m414p065_supp.pdf). Prior to retrieval of the transect tapes, echinoids were surveyed using the same five 
$50 \mathrm{~m}$ transects. Each echinoid transect was $2 \mathrm{~m}$ wide and all crevices and overhangs were carefully examined, recording all individuals found to species level (where possible).

Functional roles. To quantify the extent of various ecological processes on Ningaloo Reef, fish were grouped depending on their feeding mode (Table S2 in the supplement) into the following 4 functional groups: grazers/detritivores, browsers, scrapers and excavators, following Green \& Bellwood (2009). The physical impact on the substrata was estimated for two of these groups, bioeroding excavators (product of annual bite rate $\times$ bite volume $\times$ carbonate density $\times$ fish density) and scraping grazers (product of annual bite rate $\times$ bite area $\times$ fish density $\times$ proportion of bites on turf substratum), following Hoey \& Bellwood (2008). Bite rates, bite volume and carbonate density were taken from the literature (Bellwood 1995, Fox \& Bellwood 2007). Only individuals $\geq 15 \mathrm{~cm}$ TL were included, at which size most species exhibit adult functional capabilities (Bonaldo \& Bellwood 2008, Lokrantz et al. 2008). The impact of excavating echinoids on the substrata was also considered and their erosion estimated. Daily carbonate and algal removal rates for Echinometra mathaei and Diadema sp. were taken from the literature (Carreiro-Silva \& McClanahan 2001). Removal rates for Diadema sp. were based on average daily removal rates from $D$. setosum and $D$. savignyi. All values were estimated per transect to permit comparison among sites and habitats.

Data analysis. The relative cover of benthic substrata across the 3 habitats was examined as univariate data for the 3 major components (coral, macroalgae and CCA). The data met the requirements for normality and no transformation was needed. Changes in total community composition were also examined with a principle component analysis (PCA). A cluster analysis provided an objective delineation of the site groupings. These analyses were based on squared Euclidian distances of non-transformed data using Ward's cluster analysis. Significant variation among the clusters was evaluated using an analysis of similarity (ANOSIM).

A series of 2-way ANOVAs were used to examine potential patterns in benthic cover, fish and echinoid abundance, fish biomass and scraping and bioerosion rates by fishes and sea urchins across the shelf. Data

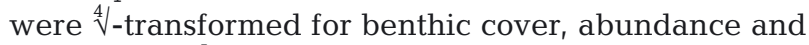
biomass and $\sqrt[5]{ }$-transformed for bioerosion and scraping to improve normality and homoscedasticity. Tukey's honestly significant difference (HSD) post hoc tests were used to identify significant differences between habitats and sites. No biomass was calculated for echinoids.

Potential relationships between percent macroalgal cover and total herbivore biomass, and macroalgal cover and the biomass of each functional group, were examined individually using Pearson's correlations. Data were $\log _{10}$-transformed for total herbivore biomass to improve linearity. The biomass for separate analysis of grazers/detritivores, browsers, scrapers and excavators needed no transformation. All statistical analyses were performed using Statistica 8.0 and Primer 5.0.

\section{RESULTS}

\section{Benthic community distribution across the shelf}

There was a clear cross-shelf gradient in the benthic community composition, with 3 distinct habitats: slope, back reef and lagoon. The ANOSIM identified the 3 significantly different habitats (global $\mathrm{r}=0.941, \mathrm{p}=$ 0.001) based on their benthic community composition, as indicated by the PCA (Fig. S1 in the supplement) and found a significant difference between the slope and lagoon $(\mathrm{r}=1.000, \mathrm{p}=0.008)$, the back reef and lagoon ( $\mathrm{r}=0.928, \mathrm{p}=0.008)$ and the back reef and slope $(r=0.896, p=0.008)$. Ningaloo Reef exhibited numerous locations dominated by macroalgae. This was restricted primarily to the lagoon where macroalgae (predominantly Sargassum) comprised about $42 \%$ total cover and was significantly different from the macroalgal cover found on the slope and back reef $\left(F_{2,204}=37.185, \mathrm{p}<0.001\right.$; Fig. $2 \mathrm{a}$, Table S3 in the supplement). Macroalgae was recorded from the back reef, but to a much lesser extent (approximately 10\% cover). Live coral was the main benthic component on the back reef $(38 \%)$ and displayed a significantly higher cover on the back reef when compared to the lagoon and slope $\left(F_{2,204}=25.352, \mathrm{p}<0.001\right)$. The slope, in general, had low complexity with $15 \%$ of the reef matrix covered by $\mathrm{CCA}_{\text {; }}$ this was significantly more than in the other 2 habitats $\left(F_{2,204}=7.802, \mathrm{p}=0.013\right.$; Fig. 2b,c, Table S3). No variation between sites was detected for any of the 3 main benthic components tested. Details of the ANOVA results and Tukey's HSD post hoc tests are given in the supplement (Tables S4a \& S5a in the supplement).

\section{Variation in functional group distribution}

The distribution of herbivorous or detritivorous functional groups reflected the changes in benthic community structure. The abundance of herbivores on the slope was dominated by echinoids (representing $97 \%$ of individuals), while fish were the numerically dominant herbivore on the back reef (69\% of individuals) and in the lagoon (99\% of individuals; Fig. 3a,b). A sig- 
nificant increase in total fish biomass was recorded from the lagoon to the slope ranging from 18 to $39 \mathrm{~kg}$ $100 \mathrm{~m}^{-2}$, respectively $\left(F_{2,60}=6.984, \mathrm{p}=0.018 ;\right.$ Fig. $3 \mathrm{c}$, Tables S4b \& S5b,c).

Echinoids displayed a marked variation in abundance across the shelf. The slope had the highest density of sea urchins, with more than 12 ind. $\mathrm{m}^{-2}$. The total abundance of sea urchins was significantly different among habitats $\left(F_{2,60}=74.139, \mathrm{p}<0.001\right)$, with both the common sea urchin Echinometra mathaei and Diadema sp. displaying highest numbers on the slope (Fig. 3a). The abundance of grazers/detritivores also
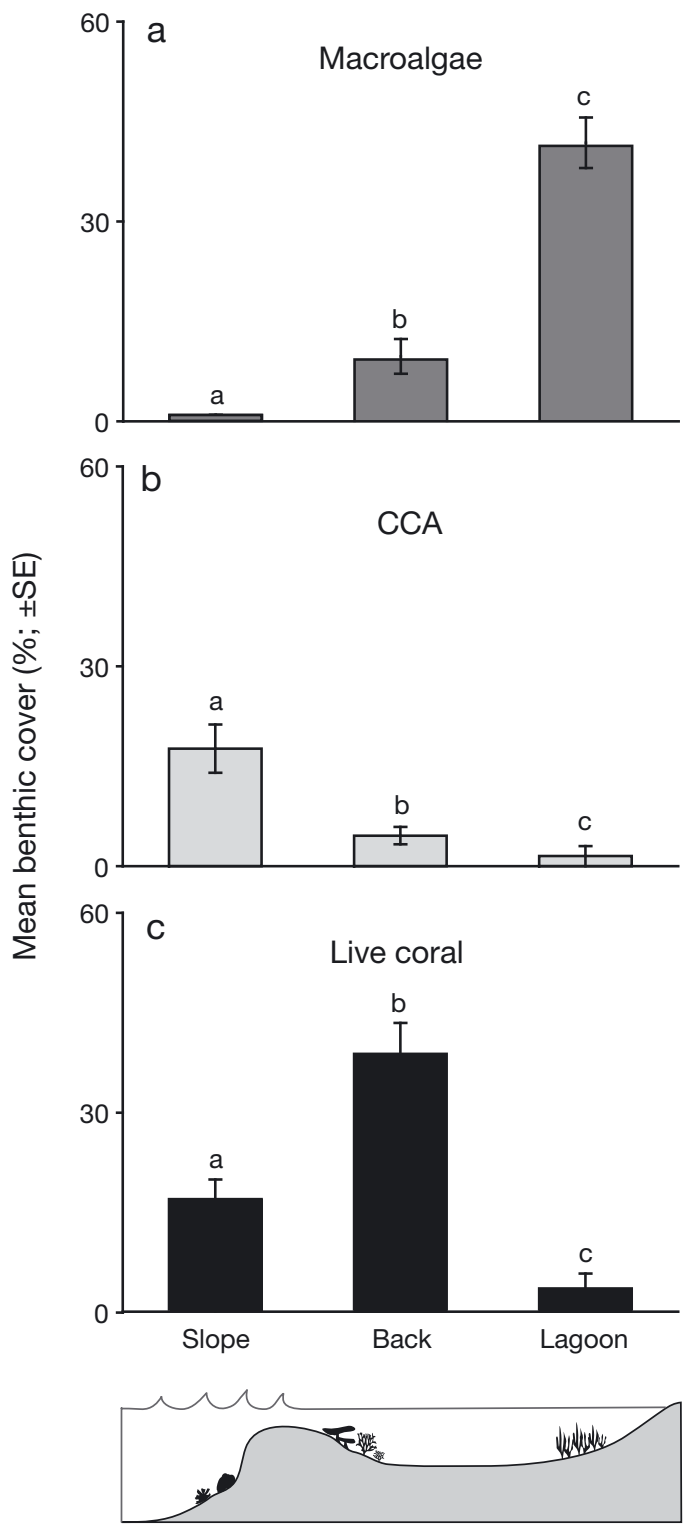

Fig. 2. Mean benthic cover (\%) across 3 habitats on Ningaloo Reef for 3 benthic groups: (a) macroalgae, (b) crustose coralline algae (CCA) and (c) live coral. SE is based on the 5 sites within each zone. Letters represent homogeneous groups identified by Tukey's HSD tests differed significantly among habitats $\left(F_{2,60}=4.773, \mathrm{p}=\right.$ 0.043), with the slope and back reef having a higher abundance than the lagoon. A similar pattern was seen for biomass $\left(F_{2,60}=4.566, \mathrm{p}=0.048\right)$, although the highest biomass was recorded on the slope (Fig. 3b,c). This pattern was explained by the presence of large
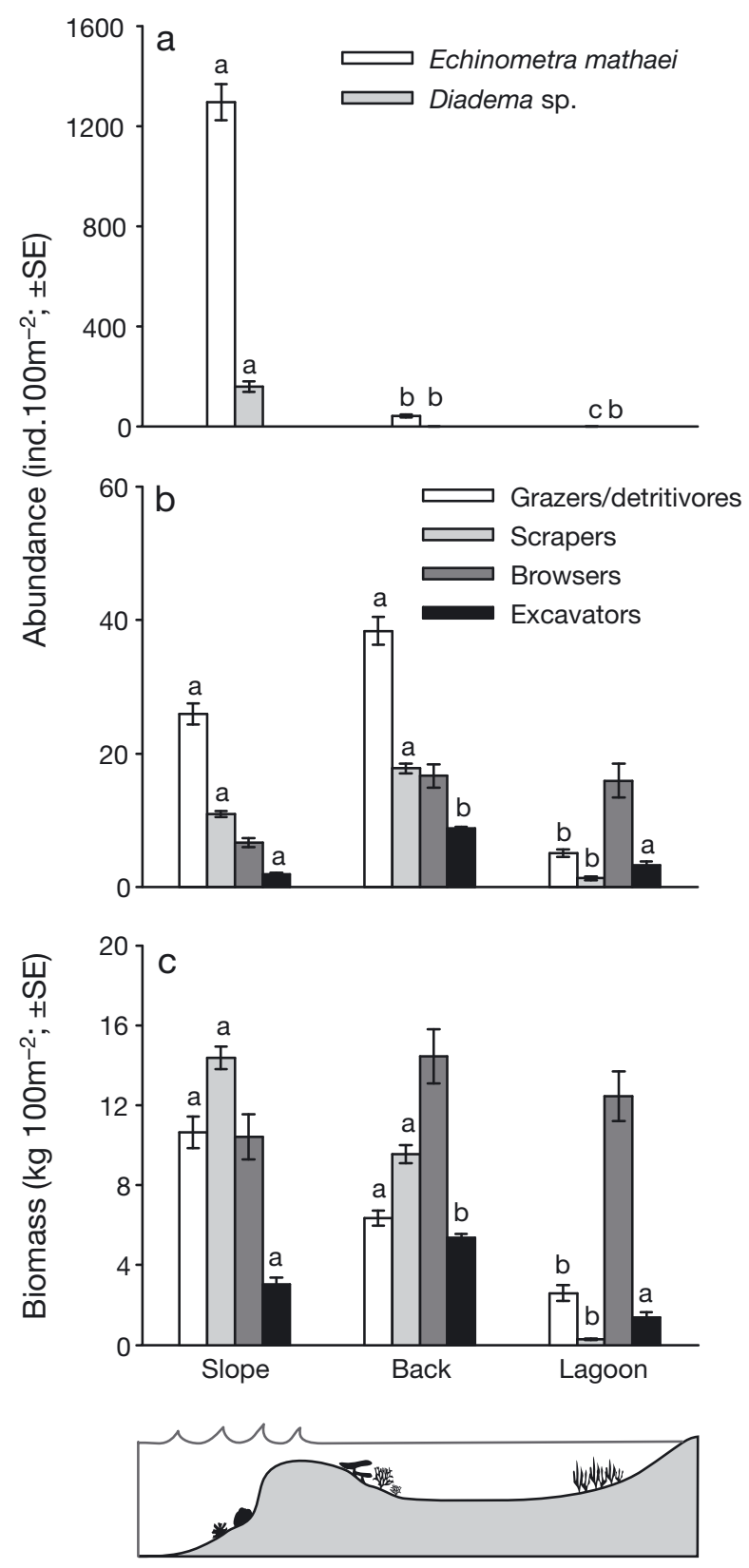

Fig. 3. Variation across 3 habitats on Ningaloo Reef for: (a) mean abundance of echinoids, (b) mean abundance and (c) mean biomass of 4 fish herbivorous functional groups. SE is based on the 5 sites within each zone. The functional groups are comprised of species in the families Acanthuridae, Kyphosidae, Labridae (scarids) and Siganidae. Letters represent homogeneous groups identified by Tukey's HSD tests 
grazing species (Acanthurus dussumeri, A. nigricauda and $A$. olivaceus) on the slope and high abundances of smaller species on the back reef (A. triostegus; Table S2).

Significant variation in scraper numbers was also recorded across the Ningaloo shelf $\left(F_{2,60}=20.938, \mathrm{p}<\right.$ 0.001). The highest abundance was found on the back reef and the lowest in the lagoon (Fig. 3b). Scraper biomass was also different among habitats $\left(F_{2,60}=21.499\right.$,
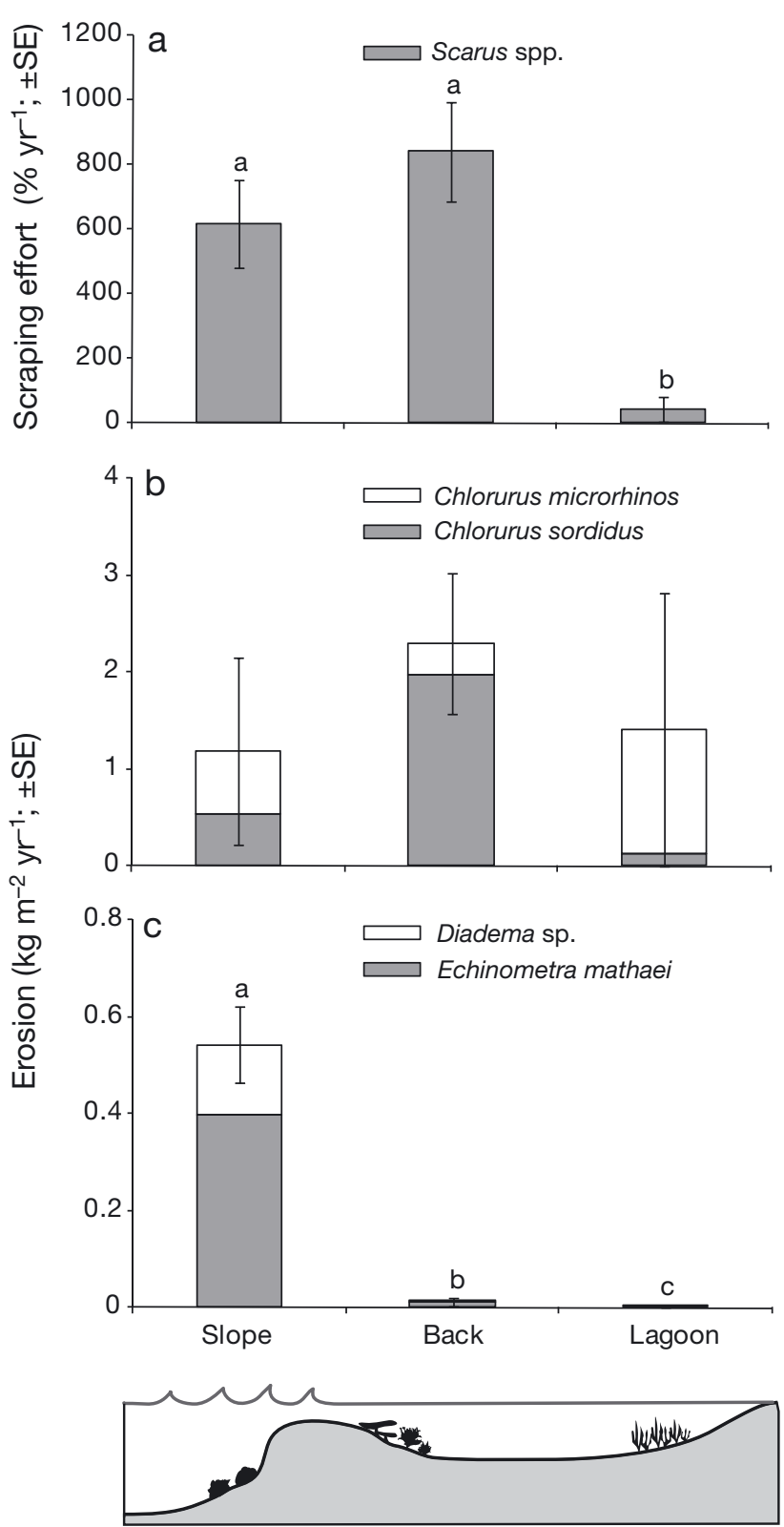

Fig. 4. Yearly physical impact across the shelf of Ningaloo Reef from: (a) fish scraping, (b) fish erosion and (c) echinoid erosion. Scraping effort estimates the area of reef scraped, expressed as the mean number of times a square meter of reef would be scraped per year $(S E, n=5)$. Letters represent homogeneous groups identified by Tukey's HSD tests $\mathrm{p}<0.001$ ), although the highest biomass was on the slope (Fig. 3c). This was a result of the presence of larger scraping species (Scarus prasiognathus and $S$. rubroviolaceus) on the slope and high abundances of smaller species on the back reef $(S$. frenatus and S. schlegeli; Table S2). For excavators, both the abundance $\left(F_{2,60}=5.427, \mathrm{p}=0.034\right)$ and biomass $\left(F_{2,60}=\right.$ 5.371, $\mathrm{p}=0.033$ ) was highest on the back reef (Fig. 3b,c, Table S4). In contrast to all other groups, no significant differences were found in the abundance of browsers across the shelf $\left(F_{2,60}=0.773, \mathrm{p}=0.493\right)$, likewise for browser biomass $\left(F_{2,60}=0.714, \mathrm{p}=0.519\right.$; Fig. 3b,c). Details of all ANOVA results and Tukey's HSD post hoc tests for abundance and biomass are given in the supplement (Tables S4b \& S5b,c).

Although a negative correlation between the biomass of scrapers and percent macroalgal cover was found $(\mathrm{r}=-0.749, \mathrm{n}=15, \mathrm{p}=0.001)$, we detected no correlation between the biomass of browsers and macroalgal cover $(r=0.194, n=15, p=0.489)$, excavators and macroalgal cover $(\mathrm{r}=-0.323, \mathrm{n}=15, \mathrm{p}=$ 0.240 ), grazers/detritivores and macroalgal cover $(\mathrm{r}=$ $-0.457, \mathrm{n}=15, \mathrm{p}=0.086$ ) or total herbivorous fish biomass and macroalgal cover $(\mathrm{r}=-0.360, \mathrm{n}=15, \mathrm{p}=$ $0.188)$.

\section{Ecosystem processes among habitats}

Rates for scraping on Ningaloo Reef reflect the patterns seen in abundance and biomass $\left(F_{2,60}=22.919\right.$, $\mathrm{p}<0.001$; Fig. 4). On average, based on estimated scraping rates, scraping species would scrape each square metre of the back reef of Ningaloo 8 times per year (every $43 \mathrm{~d}$ ), compared to 6 times per year (every $59 \mathrm{~d}$ ) on the slope and only 0.5 times per year (every $2.3 \mathrm{yr}$ ) in the lagoon (Fig. 4a). The scraping rates estimated for the lagoon were significantly less than for the back reef and the slope, which were not found to differ (Fig. 4a, Table S5d). Annual erosion rates on Ningaloo by excavating fishes were not found to be significantly different $\left(F_{2,60}=3.474, \mathrm{p}=\right.$ 0.082), although Chlorurus microrhinos was the main species responsible for the erosion on the slope and in the lagoon (38 and 91\%, respectively), while C. sordidus was responsible for $85 \%$ of the total erosion on the back reef (Fig. 4b). The impact from echinoids also differed significantly between habitats $\left(F_{2,60}=112.716, \mathrm{p}<0.001\right)$, and was over $90 \%$ higher on the slope compared to the back reef and lagoon (Fig. 4c). The high abundance of Echinometra mathaei resulted in markedly higher erosion rates when compared to Diadema sp. Details of all ANOVA results and Tukey's HSD post hoc tests are given in the supplement (Tables S4c, S5d \& S6). 


\section{DISCUSSION}

Distinct cross-shelf patterns in both benthic community structure and ecosystem function were found in the study areas of Ningaloo Reef. The 3 habitats slope, back reef and lagoon - were clearly distinct; a pattern that was present at all sites surveyed. There were 2 particularly interesting results for this relatively undisturbed reef ecosystem that warrant further discussion: (1) the presence of widespread macroalgal stands in the lagoon and (2) the high abundance of echinoids on the slope. The large stands of macroalgae were only found in the lagoon (Fig. 2a), mainly on sand-covered reef pavement and but also on a few more complex reef structures. In contrast, echinoids were by far the most abundant herbivores on the slope, with numbers reaching more than 12 ind. $\mathrm{m}^{-2}$ (Fig. 3a). Echinoids were present in extremely low numbers on the back reef and in the lagoon. These areas were instead dominated by fishes which were responsible for high scraping rates, especially on the back reef (Fig. 4a).

\section{Macroalgae}

Currently, there are 2 views dominating the question of what is driving the biomass of macroalgae in coral reef ecosystems. The prevailing view is that variation in rates of herbivory is the primary determinant of macroalgal cover (McCook 1996, Jompa \& McCook 2002, Bellwood et al. 2006, Burkepile \& Hay 2006, Sotka \& Hay 2009). However, terrestrial run-off and nutrients are also believed to be significant factors shaping the distribution of macroalgal biomass (De'ath \& Fabricius 2010). In both cases, increases in macroalgal cover are often associated with degraded ecosystems as a result of anthropogenic disturbances, especially overfishing and eutrophication (Mumby et al. 2006, Burkepile \& Hay 2009, De'ath \& Fabricius 2010).

For ecosystems with low levels of anthropogenic disturbances, factors such as overfishing and eutrophication are less likely to be important. Natural variation in the resident herbivore populations is more likely to be the primary factor shaping algal distributions. This appears to be the case for Ningaloo Reef. Due to the low levels of terrestrial input, the small resident human population and the isolation of Ningaloo Reef, terrestrially derived nutrients may be discounted as a significant factor enhancing fleshy macroalgal cover. However, the low abundance of herbivores in the lagoon probably allows for unimpeded growth and spread of macroalgae within the lagoonal areas. This situation appears to be the natural status of this reef ecosystem. In this example, low herbivory within the lagoon is probably a natural phenomenon; a result of the lack of hard 3-dimensional reefal structures within the lagoon (McCook 1997, Williams et al. 2001, Fox \& Bellwood 2007). The lagoon, therefore, provides adequate hard substratum for macroalgal growth, but insufficient 3-dimensional structure to support herbivore populations capable of limiting macroalgal development.

The abundant populations of herbivores on the back reef, as well as the negative correlation between scraper biomass and macroalgal cover, suggests that the herbivory on the back reefs of Ningaloo is sufficient to suppress macroalgal growth in this zone. This highlights the potential importance of complex habitats on Ningaloo for supporting herbivorous fish populations.

\section{Echinoids}

High abundances of echinoids (particularly Echinometra mathaei) were found on the slope of Ningaloo Reef. Similar densities ( $>12$ ind. $\mathrm{m}^{-2}$ ) have previously been recorded in what are considered to be degraded reef ecosystems, especially in sheltered habitats (Bak 1990, Carreiro-Silva \& McClanahan 2001). The presence of $E$. mathaei on wave-washed dynamic reefs has been reported from rocky or temperate environments (Glynn et al. 1979, Vanderklift et al. 2009) and occasionally from shallow, wave-exposed tropical coral reefs (Russo 1980). It is noteworthy that echinoids on Ningaloo are found in numbers that previously have been recorded primarily from degraded coral reefs. Furthermore, it is unusual to find them in such densities on the slope, the most exposed of the studied habitats. For Ningaloo, 2 aspects are worth discussing: (1) predation pressure and (2) burrowing behaviour.

Echinometra mathaei is known for its ability to create burrows using its feeding apparatus as well as spine abrasion. This results in the formation of burrows that protect the sea urchin from predation (McClanahan 1988). Although abundances of echinoid predators were not counted in the present study, this may be a significant factor controlling the distribution of sea urchins on Ningaloo. Triggerfish (Balistidae) have been identified as the main echinoid predator on coral reefs, but sparids, labrids, haemulids and lethrinids have all been shown to feed on sea urchins (McClanahan 1995). However, given that all censuses were inside or on the border of sanctuary zones, it appears unlikely that the high densities of sea urchins are a result of overfishing of fish predators.

As Echinometra mathaei creates its own protective burrows, it may be selectively advantaged in areas of low structural complexity. In these highly exposed and 
wave-swept environments it is essential for the sea urchins to stay within the crevices to avoid being dislodged. Ogden \& Lobel (1978) and Vanderklift et al. (2009) have shown that under these conditions, sea urchins adopt a sit-and-wait behaviour known as driftfeeding, where individuals feed primarily on food that accumulates in their burrows, only leaving their burrows for very short feeding events within their immediate neighbourhood. Given the high wave activity on Ningaloo, the slope may provide a more energyefficient environment where food availability in relation to energy loss is maximised.

The high numbers of echinoids on the slope is most likely a combination of the above, where low predation pressure and high water movement on a carbonate reef base provide suitable territory for the maintenance of high sea urchin densities. The high abundance of sea urchins on the slope appears not to be an outbreak as a result of direct anthropogenic disturbance, but may well be an ecological and biological component adapted to this high-wave energy environment. Nevertheless, the importance of the impact from echinoids clearly needs further investigation to fully comprehend their role on Ningaloo Reef.

\section{Functional evaluations}

Coral reefs around the world have shown that unsustainable human impacts and inadequate management can reduce the capacity of coral reefs to cope with various anthropogenic and natural disturbances, forcing them into alternative states (Jackson et al. 2001, Pandolfi et al. 2003, Bellwood et al. 2004, Norström et al. 2009). High macroalgal cover and high echinoid densities have both previously been presented as indicators of degraded marine environments (Hughes 1994, McClanahan \& Mutere 1994, Mumby et al. 2006). However, the present study suggests that, in some locations, high macroalgae and echinoid densities may represent a natural condition, and that they can act as important ecosystem components in lessimpacted coral reef ecosystems. The highly abundant Echinometra mathaei contributed to one-third of total erosion on the slopes of Ningaloo. The rarity or absence of large excavating parrotfish species in this survey (e.g. Chlorurus microrhinos and the outer GBR excavator Bolbometopon muricatum respectively; Hoey \& Bellwood 2008) makes echinoid erosion a significant process on Ningaloo.

Ningaloo Reef is unusual in 3 ways: (1) it supports the largest coral reef on the west coast of any continent; (2) the influence from the warm, south-flowing Leeuwin Current is essential for its coral reef growth; and (3) Ningaloo is relatively unaffected by human development and suffers little input from terrestrial run-off. These characteristics strongly suggest that this reef ecosystem is unusual. Additionally, the presence of vast macroalgal beds along the coast, and the importance of echinoids for bioerosion on the slope, reflect the atypical functional configuration of this ecosystem. The findings of the present study have revealed another alternative state for a coral reef ecosystem, where macroalgae and sea urchins play important roles in ecological processes and where they are not necessarily bio-indicators of reef degradation. Although Ningaloo is the only known fringing reef system of its size on the west coast of a continent in the world, it offers valuable insight into the potential diversity of ecosystem processes within and among coral reef systems.

Macroalgae and sea urchins do not appear to be bio-indicators of coral reef decline on Ningaloo Reef. Indeed, they may be important players in various ecosystem processes. While an increase in macroalgal cover or echinoids can indicate ecosystem shifts and a move to a more degraded state, high abundances of the 2 taxa per se may not necessarily be indicators of human disturbance. They are characteristic features of degraded states but they do not define this condition. It is the change in densities, not the densities per se that are important. Given the unusual functional structure of Ningaloo, its proximity to shore and potential for human impact, Ningaloo Reef may be vulnerable. The inevitable increase in human impacts on this reef ecosystem will require careful management if we are to avoid jeopardizing the health of Ningaloo.

\section{CONCLUSIONS}

The present study has highlighted the unusual benthic and functional composition of Ningaloo Reef. The results revealed unexpectedly high densities of echinoids and macroalgae, 2 common bio-indicators of coral reef decline. Yet Ningaloo is one of the least human-impacted large coral reef ecosystems in the world. At first glance (using traditional metrics for reef degradation) it appears that Ningaloo is showing signs of decline. However, the high abundance of macroalgae in the lagoon and sea urchins on the slope may well be a natural feature of this ecosystem rather than another example of human-induced decline. Nevertheless, Ningaloo does face increasing pressure from human development and its unusual functional characteristics may make it particularly vulnerable. Careful management will be vital if we wish to maintain a resilient coral reef ecosystem in the face of increasing human activity. 
Acknowledgements. We thank T. Mannering and C. Birrell for field assistance; the Australian Institute of Marine Science for logistical support; AIMS@JCU (C.L.J.) and the Australian Research Council (D.R.B.) for financial support; D. J. Crossman, colleagues in the Centre of Excellence, 2 anonymous reviewer, and C. Birkeland for valuable comments.

\section{LITERATURE CITED}

Bak RPM (1990) Patterns of echinoid bioerosion in two Pacific coral reef lagoons. Mar Ecol Prog Ser 66:267-272

Bellwood DR (1995) Direct estimate of bioerosion by two parrotfish species, Chlorurus gibbus and C. sordidus, on the Great Barrier Reef, Australia. Mar Biol 121:419-429

Bellwood DR, Hughes TP, Folke C, Nyström M (2004) Confronting the coral reef crisis. Nature 429:827-833

Bellwood DR, Hughes TP, Hoey AS (2006) Sleeping functional group drives coral reef recovery. Curr Biol 16:2434-2439

Bonaldo RM, Bellwood DR (2008) Size-dependent variation in the functional role of the parrotfish Scarus rivulatus on the Great Barrier Reef, Australia. Mar Ecol Prog Ser 360: 237-244

Bruno JF, Sweatman H, Precht WF, Selig ER, Schutte VGW (2009) Assessing evidence of phase shifts from coral to macroalgal dominance on coral reefs. Ecology 90: 1478-1484

Burkepile DE, Hay ME (2006) Herbivore vs. nutrient control of marine primary producers: context-dependent effects. Ecology 87:3128-3139

Burkepile DE, Hay ME (2008) Herbivore species richness and feeding complementarity affect community structure and function on a coral reef. Proc Natl Acad Sci USA 105:16201-16206

Burkepile DE, Hay ME (2009) Nutrient versus herbivore control of macroalgal community development and coral growth on a Caribbean reef. Mar Ecol Prog Ser 389: 71-84

> Carreiro-Silva M, McClanahan TR (2001) Echinoid bioerosion and herbivory on Kenyan coral reefs: the role of protection from fishing. J Exp Mar Biol Ecol 262:133-153

Cassata L, Collins LB (2008) Coral reef communities, habitats, and substrates in and near sanctuary zones of Ningaloo Marine Park. J Coast Res 24:139-151

> Collins LB, Zhu ZR, Wyrvoll KH, Eisenhauer A (2003) Late Quaternary structure and development of the northern Ningaloo Reef, Australia. Sediment Geol 159:81-94

$>$ De'ath G, Fabricius K (2010) Water quality as a regional driver of coral biodiversity and macroalgae on the Great Barrier Reef. Ecol Appl 20:840-850

De'ath G, Lough JM, Fabricius KE (2009) Declining coral calcification on the Great Barrier Reef. Science 323:116-119

Done TJ (1992) Phase shifts in coral reef communities and their ecological significance. Hydrobiologia 247:121-132

> Done T, Turak E, Wakeford M, DeVantier L, McDonald A, Fisk D (2007) Decadal changes in turbid water coral communities at Pandora Reef: Loss of resilience or too soon to tell? Coral Reefs 26:789-805

Fabricius KE, De'ath G, Puotinen ML, Done T, Cooper TF, Burgess SC (2008) Disturbance gradients on inshore and offshore coral reefs caused by a severe tropical cyclone. Limnol Oceanogr 53:690-704

> Fox RJ, Bellwood DR (2007) Quantifying herbivory across a coral reef depth gradient. Mar Ecol Prog Ser 339:49-59

Fulton CJ, Bellwood DR, Wainwright PC (2001) The relationship between swimming ability and habitat use in wrasses (Labridae). Mar Biol 139:25-33
Furnas M (2007) Intra-seasonal and inter-annual variations in phytoplankton biomass, primary production and bacterial production at North West Cape, Western Australia: links to the 1997-1998 El Niño event. Cont Shelf Res 27: 958-980

> Glynn PW, Wellington GM, Birkeland C (1979) Coral reef growth in Galapagos: limitations by sea urchins. Science 203:47-49

Graham NAJ, Wilson SK, Jennings S, Polunin NVC, Robinson J, Bijoux JP, Daw TM (2007) Lag effects in the impacts of mass coral bleaching on coral reef fish, fisheries, and ecosystems. Conserv Biol 21:1291-1300

Green AL, Bellwood DR (2009) Monitoring functional groups of herbivorous reef fishes as indicators of coral reef resilience. A practical guide for coral reef managers in the Asia Pacific region. IUCN working group on Climate Change and Coral Reefs, IUCN, Gland

Hanson CE, Pattiaratchi CB, Waite AM (2005) Sporadic upwelling on a downwelling coast: phytoplankton responses to spatially variable nutrient dynamics off the Gascoyne region of Western Australia. Cont Shelf Res 25: 1561-1582

> Hart AM, Klumpp DW (1996) Response of herbivorous fishes to crown-of-thorns starfish Acanthaster planci outbreaks. I. Substratum analysis and feeding ecology of Acanthurus nigrofuscus and Scarus frenatus. Mar Ecol Prog Ser 132: $11-19$

Hay ME (1984) Patterns of fish and urchin grazing on Caribbean coral: Are previous results typical? Ecology 65: 446-454

> Hoey AS, Bellwood DR (2008) Cross-shelf variation in the role of parrotfishes on the Great Barrier Reef. Coral Reefs 27: 37-47

> Hughes TP (1994) Catastrophes, phase shifts, and large-scale degradation of a Caribbean coral reef. Science 265: $1547-1551$

Hughes TP, Baird AH, Bellwood DR, Card M and others (2003) Climate change, human impacts, and the resilience of coral reefs. Science 301:929-933

> Hughes TP, Rodrigues MJ, Bellwood DR, Ceccarelli D and others (2007) Phase shifts, herbivory, and the resilience of coral reefs to climate change. Curr Biol 17:360-365

> Jackson JBC, Kirby MX, Berger WH, Bjorndal KA and others (2001) Historical overfishing and the recent collapse of coastal ecosystems. Science 293:629-637

Jompa J, McCook LJ (2002) Effects of competition and herbivory on interactions between a hard coral and a brown alga. J Exp Mar Biol Ecol 271:25-39

> Ledlie MH, Graham NAJ, Bythell JC, Wilson SK, Jennings S, Polunin NVC, Hardcastle J (2007) Phase shifts and the role of herbivory in the resilience of coral reefs. Coral Reefs 26: 641-653

Lokrantz J, Nyström M, Thyresson M, Johansson C (2008) The non-linear relationship between body size and function in parrotfishes. Coral Reefs 27:967-974

> Lough JM (2008) 10th anniversary review: a changing climate for coral reefs. J Environ Monit 10:21-29

McClanahan TR (1988) Coexistence in a sea urchin guild and its implications to coral reef diversity and degradation. Oecologia 77:210-218

McClanahan TR (1995) Fish predators and scavangers of the sea urchin Echinometra mathaei in Kenyan coral reef marine parks. Environ Biol Fishes 43:187-193

> McClanahan TR, Mutere JC (1994) Coral and sea urchin assemblage structure and interrelationships in Kenyan reef lagoons. Hydrobiologia 286:109-124

McCook LJ (1996) Effects of herbivores and water quality on Sargassum distribution on the central Great Barrier Reef: cross-shelf transplants. Mar Ecol Prog Ser 139:179-192 
McCook LJ (1997) Effects of herbivory on zonation of Sargassum spp. within fringing reefs of the central Great Barrier Reef. Mar Biol 129:713-722

McCook LJ (1999) Macroalgae, nutrients and phase shifts on coral reefs: scientific issues and management consequences for the Great Barrier Reef. Coral Reefs 18: 357-367

McManus JW, Polsenberg JF (2004) Coral-algal phase shifts on coral reefs: ecological and environmental aspects. Prog Oceanogr 60:263-279

Moran M, Edmonds J, Jenke J, Cassells G, Burton C (1993) Fisheries biology of emperors (Lethrinidae) in north-west Australian coastal waters. Department of Fisheries, Western Australia, Perth

Mumby PJ, Dahlgren CP, Harborne AR, Kappel CV and others (2006) Fishing, trophic cascades, and the process of grazing on coral reefs. Science 311:98-101

Norström AV, Nyström M, Lokrantz J, Folke C (2009) Alternative states on coral reefs: beyond coral-macroalgal phase shifts. Mar Ecol Prog Ser 376:295-306

Nyström M, Graham NAJ, Lokrantz J, Norström AV (2008) Capturing the cornerstones of coral reef resilience: linking theory to practice. Coral Reefs 27:795-809

Ogden JC, Lobel PS (1978) The role of herbivorous fishes and urchins in coral reef communities. Environ Biol Fish 3: 49-63

Paddack MJ, Reynolds JD, Aguilar C, Appeldoorn RS and others (2009) Recent region-wide declines in Caribbean reef fish abundance. Curr Biol 19:590-595

Pandolfi JM, Bradbury RH, Sala E, Hughes TP and others (2003) Global trajectories of the long-term decline of coral reef ecosystems. Science 301:955-958

Roberts CM, McClean CJ, Veron JEN, Hawkins JP and others (2002) Marine biodiversity hotspots and conservation priorities for tropical reefs. Science 295:1280-1284

Editorial responsibility: Charles Birkeland,

Honolulu, Hawaii, USA
Russo AR (1980) Bioerosion by two rock boring echinoids (Echinometra mathaei and Echinostrephus aciculatus) on Enewetak Atoll, Marshall Islands. J Mar Res 38:99-110

Schaffelke B (1999) Short-term nutrient pulses as tools to assess responses of coral reef macroalgae to enhanced nutrient availability. Mar Ecol Prog Ser 182:305-310

Sotka EE, Hay ME (2009) Effects of herbivores, nutrient enrichment, and their interactions on macroalgal proliferation and coral growth. Coral Reefs 28:555-568

Vanderklift MA, Lavery PS, Waddington KI (2009) Intensity of herbivory on kelp by fish and sea urchins differs between inshore and offshore reefs. Mar Ecol Prog Ser 376:203-211

Vroom PS, Page KN, Kenyon JC, Brainard RE (2006) Algaedominated reefs. Am Sci 94:430-437

Vroom P, Musburger C, Cooper S, Maragos J, Page-Albins K, Timmers M (2010) Marine biological community baselines in unimpacted tropical ecosystems: spatial and temporal analysis of reefs at Howland and Baker Islands. Biodivers Conserv 19:797-812

Wilkinson C (ed) (2008) Status of coral reefs of the world: 2008, Vol 1. Global Coral Reef Monitoring Network and Reef Rainforest Research Centre, Townsville

- Williams ID, Polunin NVC, Hendrick VJ (2001) Limits to grazing by herbivorous fishes and the impact of low coral cover on macroalgal abundance on a coral reef in Belize. Mar Ecol Prog Ser 222:187-196

> Wismer S, Hoey AS, Bellwood DR (2009) Cross-shelf benthic community structure on the Great Barrier Reef: relationships between macroalgal cover and herbivore biomass. Mar Ecol Prog Ser 376:45-54

Woo M, Pattiaratchi C, Schroeder W (2006) Summer surface circulation along the Gascoyne continental shelf, Western Australia. Cont Shelf Res 26:132-152

Submitted: November 30, 2009; Accepted: July 10, 2010

Proofs received from author(s): August 31, 2010 